\title{
ANALISIS PERCAKAPAN DALAM ACARA "TALK SHOW KICK ANDY DENGAN PENGARANG NOVEL NEGERI LIMA MENARA"
}

\author{
Zulfatun Anisah \\ STAI AL HIKMAH TUBAN \\ Email: zulfa7664@gmail.com
}

\begin{abstract}
ABSTRAK: "Analisis percakapan yang terdapat dalam video Talk Show Kick Andy memuat empat pokok bahasan, diantaranya topik percakapan, struktur percakapan, alih tutur percakapan, dan kepaduan wacana percakapan. Pada topik percakapan ditemukan tiga topik, yakni topik umum, topik yang berkelanjutan dan topik nyata. Selanjutnya, pada struktur percakapan ditemukan topik percakapan yang terdapat pada awal percakapan, inti percakapan, dan akhir percakapan. Adapun alih tutur percakapan berisi dua tipe alih tutur percakapan. Pertama alih tutur dengan giliran diatur, kedua Alih tutur dengan giliran otomatis. Analisis percakapan yang terkhir yaitu kepaduan wacana percakapan. Kepaduan ditunjukkan pada kohesi dan koherensi yang ada dalam isi percakapan dari awal hingga akhir percakapan."
\end{abstract}

Kata Kunci: analisis percakapan, topik percakapan, alih tutur percakapan.

\section{PENDAHULUAN}

Kegiatan berinteraksi selalu melibatkan dua pihak yang berposisi sebagai pembicara dan pendengar. Silih bergantinya posisi dapat terjadi dimanapun, kapanpun, dan dengan siapapun sesuai dengan kebutuhan pembicaraan. Pembicara boleh saja satu, namun pendengar tentu bisa lebih banyak, seperti yang terjadi pada acara talkshaw Kick Andy yang disiarkan di Metro TV setiap Jumat pukul 21.30-23.00 WIB dengan bintang tamu yang dihadirkan. Hal ini seperti yang dikatakan oleh Kridalaksana bahwa percakapan adalah satuan interaksi bahasa antara dua pembicara atau lebih. ${ }^{1}$

Acara Kick Andy! adalah sebuah acara Talk Show atau bincang-bincang yang mengetengahkan topik dari segala bidang, mulai dari persoalan pendidikan, sosial, kesehatan, politik, entertainment dan berbagai persoalan yang dihadapi oleh masyarakat. Dengan begitu, bintang tamu yang dihadirkan pun juga dari latar belakang yang berbeda, disesuaikan dengan tema pada saat itu. Selain menghibur Kick Andy juga memberikan informasi, edukasi, motivasi dan inspirasi bagi pamirsanya. Hal inilah yang

\footnotetext{
${ }^{1}$ Kridalaksana, Kamus Linguistik Edisi Keempat,( Jakarta: Gramedia Pustaka Utama, 2011), 188
} 
menarik perhatian peneliti untuk meneliti salah satu percakapan yang terdapat dalam acara talk show Kick Andy yakni pada episode "percakapan Andy F. Noya bersama pengarang Novel "Negeri Lima Menara", Anwar Fuadi.

Percakapan yang terdapat dalam acara Kick Andy pada episode tersebut membahas tentang makna dari isi novel dan kesuksesan penjualan novel Negeri Lima Menara. Dalam percakapan tersebut terjadi penyampaian pesan dari pewawancara kepada orang yang diwawancarai, dan sebaliknya.

Berdasarkan persoalan yang telah dikemukakan di atas maka peneliti tertarik untuk meneliti percakapan tersebut dari segi struktur percakapan, topik percakapan, alih tutur dan kepaduan wacana percakapan. Adapun hasil analisis data dapat diketahui dalam bagian pembahasan.

\section{KONSEP DASAR}

\section{Pengertian Analisis Percakapan}

Parera menyatakan bahwa Analisis percakapan (Anacap) merupakan salah satu cabang dari analisis wacana (Anawac). ${ }^{2}$ Namun, keduanya memiliki perbedaan dalam hal analisis wacana bentuk tulis. Kalimat yang tampaknya dalam anawac tulis tidak koheren, dapat menjadi koheren dalam anacap. Anacap sendiri memiliki dua komponen komunikasi yang menentukan, yakni komponen isyarat bahasa dan isyarat yang lain (komponen verbal dan komponen nonverbal).

Percakapan merupakan satu kegiatan atau peristiwa berbahasa lisan antara dua atau lebih penutur yang saling memberikan informasi dan mempertahankan hubungan yang baik. Untuk dapat melangsungkan kegiatan berbahasa lisan antar penutur, maka kita perlu menelaah dan menganalisis komponen-komponen apa saja yang diperlukan dan bagaimana pengelolaan kegiatan percakapan.Anacap tidak mempersoalkan apa isi percakapan dan bagaimana cara isi percakapan itu disampaikan. Anacap hanya akan mempersoalkan bagaimana pengelolaan satu percakapan agar tercapai sampai ke tujuan percakapan, yakni berbagai informasi dan berbagai hubungan yang baik.

\footnotetext{
${ }^{2}$ Parera, Teori Semantik, (Jakarta: Airlangga, 1991), 129
} 
Brown mengemukakan bahwa analisis percakapan mempunyai tiga asumsi (1) interaksi diorganisasikan secara terstruktur, (2)kontribusi terhadap suatu interaksi diorientasikan secara kontekstual, dan (3) kedua karakter tersebut berada dalam detaildetail interaksi sehingga tidak ada satu detail urutan pun yang dapat dilewatkan secara apriori sebagai sesuatu yang tidak teratur, suatu kebetulan atau suatu hal yang tidak relevan. ${ }^{3}$

\section{Topik Percakapan}

Howe menganggap bahwa topik merupakan syarat terbentuknya wacana percakapan. ${ }^{4}$ Analisis topik dalam wacana tidak cukup dengan menganalisis sebuah kalimat. Topik itu dapat diidentifikasi bila analisis wacana memahami konteks wacana yang mendukungnya. Bukan ko-teks yang membantu pemahaman, namun kontekslah yang memberikan pengaruh besar dalam mendukung atau menambah kejelasan makna. Konteks itu berupa situasi yang ada hubungannya dengan kejadian tertentu.

Topik dalam wacana percakapan sering berganti. Samsuri menegaskan bahwa dua orang peserta percakapan dapat berbicara dengan dua topik yang berbeda. ${ }^{5}$ Lebih jelasnya, dalam satu peristiwa pembicaraan, para peserta percakapan dapat mengembangkan topiknya masing-masing. Ada topik inti, kemudian dikembangkan ke berbagai topik bawahan.

Pembagian topik percakapan ada dua. Pertama, topik umum yaitu pokok pangkal pembicaraan yang berperan sebagai judul atau tema. Topik ini yang mengarahkan seluruh percakapan, sehingga tujuan percakapan bisa tercapai. Kedua, topik-topik kecil yaitu aspek-aspek tertentu yang timbul dalam rangkaian keseluruhan percakapan ${ }^{6}$. Kadang-kadang topik-topik itu berubah-ubah dan meloncat-loncat seirama dengan situasi percakapan.

Selanjutnya, berdasarkan tipenya, topik dibagi menjadi empat, antara lain (1) topik yang berkelanjutan, (2) topik yang tidak berkelanjutan, (3) topik nyata, dan (4)

\footnotetext{
${ }^{3}$ Brown\&Yule, Analisis Wacana, Penerjemah I. Soetikno, (Jakarta: P.T. Gramedia, 1996), 236

${ }^{4}$ Howe, Acquiring Languange in Converstional Context, (London: Academic Press Inc., 1981), 5

${ }^{5}$ Samsuri, Analisis Wacana, (Malang: IKIP Malang, 1989), 17-20

${ }^{6}$ Syamsudin, Studi Wacana Teori-Analisis-Pengajaran, (Bandung: Mimbar Pendidikan Bahasa dan Seni FPBS IKIP Bandung, 1992), 55
} 
topik imajiner ${ }^{7}$. Teori ini pula yang akan digunakan dalam membedah percakapan yang terjadi antara Andi dengan pengarang novel "Negeri Lima Menara".

\section{Struktur Percakapan}

Salah satu asumsi analisis percakapan ialah interaksi dalam suatu percakapan diorganisasikan secara struktural. ${ }^{8}$ Struktur organisasi percakapan berkaitan erat dengan pasangan ujar terdekat. Pasangan ujar terdekat merupakan urutan dua ujaran yang dihasilkan oleh penutur-penutur yang berbeda. Bagian ujaran yang pertama memunculkan bagian yang kedua, misalnya pada percakapan video Andy F. Noya dengan Ahmad Fuadi, apa yang dipertanyaan Andy dijawab oleh Fuadi.

Identifikasi terhadap pasangan ujar terdekat merupakan masalah pokok dalam analisis percakapan. Ini dapat dilakukan dengan cara mengidentifikasi pola-pola urutan yang diterapkan pada ujaran-ujaran dalam interaksi tersebut. Guna mengetahui koherensi suatu percakapan. Pasangan ujar terdekat diartikan sebagai ujaran-ujaran yang dihasilkan oleh dua orang penutur yang berurutan. Ujaran kedua diidentifikasi mempunyai hubungan dan merupakan tindak lanjut dari ujaran pertama. Ungkapan tersebut mengutip pernyataan Choultard yang menyatakan bahwa pasangan ujar terdekat merupakan unit struktur dasar dalam suatu percakapan. ${ }^{9}$

Dalam pasangan ujar terdekat, ujaran kedua sebagai tanggapan atau respon dari ujaran pertama. Ujaran dapat dipilah menjadi dua macam, yaitu ujaran yang disukai dan ujaran yang tidak disukai. ${ }^{10}$ Ujaran yang berisi permintaan dapat memunculkan respon dikabulkan atau ditolak. Pengabulan merupakan respon yang disukai, sementara pengelakan atau penolakan menjadi respon yang tidak disukai.

Hubungan antara ujaran pertama dan kedua dalam pasangan ujar terdekat digambarkan oleh Levinson sebagai berikut:

\footnotetext{
${ }^{7}$ Rani, “Analisis Percakapan Anak-anak Antarteman Sebaya”, Tesis Tidak dipublikasikan, (Malang: PBS IKIP Malang, 1992), 14

${ }^{8}$ Syamsudin, Studi Wacana Teori-Analisis-Pengajaran...236

${ }^{9}$ Coulthard, An Introduction to Discourse Analysis, (New York: Longman, 1985), 73

${ }^{10}$ Levinson, Pragmatics, (Cambrige: Cambridge University Press, 1983), 336
} 
Tabel 1

Hubungan ujaran pertama dan Ujaran Kedua

\begin{tabular}{|c|c|c|}
\hline \multirow{2}{*}{$\begin{array}{c}\text { Ujaran } \\
\text { Pertama }\end{array}$} & \multicolumn{2}{|c|}{ Ujaran Kedua } \\
\hline & Disukai & Tidak disukai \\
\hline Permintaan & Pengabulan & Penolakan \\
\hline Penawaran & Penerimaan & Penolakan \\
\hline Penilaian & Persetujuan & Ketidaksetujuan \\
\hline Pertanyaan & Jawaban yang tidak diharapkan & $\begin{array}{l}\text { Jawaban yang tidak diharapkan/tidak } \\
\text { dijawab }\end{array}$ \\
\hline Penyalahan & Penyangkalan & Pengiyaan \\
\hline
\end{tabular}

Pemilahan secara dikotomis ujaran kedua sebagai tanggapan yang disukai dan

tidak disukai dalam konteks tertentu agak sulit diterima. Misalnya dalam konteks ujaran pertama sebagai suatu pujian. Ujaran kedua yang muncul sebagai respon menjadi beragam. Respon yang diberikan dapat berupa penerimaan, persetujuan, pergeseran, dan pembalikan.

\section{Alih Tutur}

Menurut Schiffrin aturan yang dapat diterapkan dalam alih tutur sebagai berikut $^{11}$ :

a. Jika alih tutur itu telah ditentukan dengan menunjuk pembicara berikutnya, maka peserta yang ditunjuk itulah yang berhak untuk berbicara pada giliran berikutnya;

b. Jika alih tutur tidak ditentukan sebelumnya, maka peserta percakapan itu akan menentukan siapa yang harus berbicara pada giliran setelah pembicara sebelumnya memberikan kesempatan pada peserta lainnya;

c. Jika alih tutur tidak ditentukan sebelumnya dan peserta lain tidak mengambil inisiatif untuk menjadi pembicara, maka pembicara yang terdahulu dapat melanjutkan pembicaraannya.

Kaidah yang mengatur alih tutur sangat bergantung pada tipe suatu peristiwa tutur. Kaidah alih tutur di kelas, dalam suatu debat, dalam keluarga, dalam percakapan sehari-hari tentu akan berbeda-beda. Lebih lanjut dikemukakan bahwa kaidah alih tutur bervariasi, bergantung pada budaya suatu masyarakat.

Adapun dalam hal berbagi kesempatan berbicara Syamsudin membaginya menjadi empat macam, diantaranya: (1) giliran otomatis, (2) giliran diatur, (3) giliran

\footnotetext{
${ }^{11}$ Schiffrin, Approach to Discours... 238
} 
direbut, dan (4) giliran sukarela. ${ }^{12}$ Giliran otomatis dapat ditemui pada percakapan yang melibatkan dua orang partisipan. Ketika seseorang memberi salam secara otomatis lawan tuturnya menjawab dengan salam. Giliran diatur dijumpai pada percakapan formal. Dalam percakapan formal yang diatur oleh seorang pemandu atau moderator, kesempatan berbicara digilir secara teratur. Giliran direbut dapat dijumpai pada suatu pertengkaran atau diskusi bebas dengan situasi yang sangat panas. Sedangkan giliran sukarela dapat ditemukan pada percakapan yang bersifat tukar pendapat. Seseorang yang memahami betul persoalan yang dibicarakan secara sukarela akan mengambil kesempatan berbicara.

\section{Kepaduan Wacana Percakapan}

Istilah kepaduan wacana mempunyai hubungan yang erat dengan kohesi dan koherensi. Istilah kohesi mengacu pada hubungan secara semantis antara bagian yang satu dengan bagian lain dalam sebuah teks. Hubungan itu ditandai dengan penggunaan penghubung formal atau penanda. ${ }^{13}$ Sementara koherensi merupakan hubungan secara semantis antara bagian yang satu dengan bagian yang lain dalam teks yang tidak didukung oleh penggunaan penghubung formal. ${ }^{14}$ Hemat kalimat, pendapat mengenai kepaduan wacana dapat disimpulkan bahwa kohesi itu merujuk pada perpautan bentuk, sedangkan koherensi merujuk pada pertautan makna. ${ }^{15}$

\section{Metode Penelitian}

Penelitian ini berjenis deskriptif kualitatif. Sumber data diambil dari studi dokumen pada situs www.youtube.com. Instrumen pengumpulan data menggunakan dokumen (non tes), sedangkan pada instrumen penaganalisisan data penelitian ini terdiri atas peneliti, kartu data, dan buku catatan penelitian. Teknik pengumpulan data dalam penelitian ini menggunakan metode dokumenter dan metode simak. Dalam penganalisisan data digunakan metode yang khusus digunakan dalam penelitian bahasa yakni metode padan. ${ }^{16}$ Dalam metode padan, alat penentunya di luar, terlepas, dan tidak

\footnotetext{
${ }^{12}$ Schiffrin, Approach to Discours... 51-52

${ }^{13}$ Halliday dan Hasan, Cohesion in English, (London: Longman, 1976), 88

${ }^{14}$ Widdowson, Teahing Languange As Communication, (Oxford: University Press, 1978), 110

${ }^{15}$ Djajasudarma, Wacana Pemahaman dan Hubungan antar Unsur, (Bandung: Eresco, 1994), 46

${ }^{16}$ Sudaryanto, Metode dan Aneka Teknik Analisis Bahasa (Pengantar Penelitian Wahana Kebudayaan Secara Linguistis), (Yogyakarta:DutaWacana University Press, 1993), 13
} 
menjadi bagian dari bahasa (langue) yang bersangkutan. Selanjutnya dalam pengujian keabsahan data dilakukan dengan cara deskripsi mendalam, triangulasi, dan replika data.

\section{Transkripsi Data}

\section{Percakapan Andi F. Noya bersama Pengarang Novel Negeri 5 Menara}

\begin{tabular}{|c|c|}
\hline $\begin{array}{c}\text { Kode } \\
\text { Percakapan }\end{array}$ & Isi percakapan \\
\hline pgntr.I & $\begin{array}{l}\text { Di tangah saya ada sebuah buku yang bercerita tentang pengalaman anak-anak } \\
\text { muda di Pesantren Gontor, Ponorogo Jawa Timur. Adalah kisah dimana mereka } \\
\text { belajar, kisah-kisah yang unik, yang lucu bahkan ada yang sedih. Mereka adalah } \\
\text { anak-anak dari kalangan bawah yang kemudian keluar dari pesantren membawa } \\
\text { mimipi mereka masing-masing. }\end{array}$ \\
\hline pgntr.II & $\begin{array}{l}\text { Buku ini sampai April lalu sudah dicetak sebanyak } 100.000 \text { eksemplar. Dan yang } \\
\text { paling membanggakan buku ini sudah dibajak. Artinya buku ini memang di sukai } \\
\text { dan dibeli oleh banyak orang. Nah, kali ini saya akan bercerita tentang siapa saja } \\
\text { enam anak muda yang ada dalam cerita ini. Penulisnya sudah ada bersama kita } \\
\text { Ahmad Fuadi. }\end{array}$ \\
\hline prckpn.1 & $\begin{aligned} & \text { Andy } \text { :"Fuadi bisa cerita, ini buku tentang apa sich?”. } \\
& \text { Fuadi : "Ini adalah sebuah kenangan Pak!". } \\
& \text { Bahwa saya itu awalnya masuk pesantren itu di paksa oleh Ibu saya. } \\
& \text { Kemudian setelah berjalan bertahun-tahun. Dan setelah tamat malah } \\
& \text { berfikir. Betapa beruntungnya saya dikirim ke Pasantren. Sangat } \\
& \text { inspiratif, membuat saya punya pegangan hidup. Kalau ini hanya saya } \\
& \text { simpan sendiri, kayaknya mubadzir. Kenapa gak dituliskan? Dan mudah- } \\
& \text { mudahan orang lain terinspirasi. }\end{aligned}$ \\
\hline prckpn. 2 & $\begin{array}{l}\text { Andy: "Mengapa judulnya Negeri } 5 \text { Menara?". } \\
\text { Fuadi : "Ini adalah simbol dari impian kami, ada enam orang yang saya } \\
\text { ceritakan di sini, mereka kawan-kawan saya, masing-masing punya } \\
\text { impian. Kalau dalam novel ini, kami duduk di sebuah menara masjid } \\
\text { sebelum magrib. Dan awan magrib yang merah itu berarah ke ufuk dan } \\
\text { dalam pikiran kami itu sebuah benua-benua dunia. Ada yang bilang kayak } \\
\text { benua Amerika, dan sebelahnya bilang "salah! Itu benua Eropa, dan satu } \\
\text { lagi bilang kamu gak nasionalis, itulah negara Indonesia. Kami semua } \\
\text { punya impian dan itu disimbolkan dengan negara-negara impian itu yang } \\
\text { akhirnya Alhamdulillah banyak yang menjadi kenyataan". }\end{array}$ \\
\hline prckpn.3 & $\begin{array}{l}\text { Andy: "Salah satu tokoh yang Anda tulis di sini, bernama raja". } \\
\text { Fuadi : "Betul". }\end{array}$ \\
\hline
\end{tabular}




\begin{tabular}{|c|c|}
\hline prckpn.4 & $\begin{array}{l}\text { Andy: "Siapa raja itu?". } \\
\text { Fuadi : "Raja ini adalah seorang anak yang jauh datang dari Medan. Dan dia } \\
\text { saking pengennya masuk pondok, di waktu itu datang terlambat, tutup. } \\
\text { Dan namanya di Gontor tutup ya gak boleh. Dia bilang, "Boleh gak saya } \\
\text { masuk? Ga boleh. Karena saking pengennya dia tidak mau pulang ke } \\
\text { Medan. Dan dia menunggu masa pembukaan tahun depan, demi untuk } \\
\text { masuk ke pesantren itu". }\end{array}$ \\
\hline prckpn.5 & $\begin{array}{l}\text { Andy : "Jadi novel ini berbasis kisah nyata ya?". } \\
\text { Fuadi :"Dia adalah novel, tapi banyak terinspirasi oleh kisah nyata teman-teman } \\
\quad \text { saya. Tentunya ada pengembangan bang!". }\end{array}$ \\
\hline prckpn.6 & $\begin{array}{l}\text { Andy : "Nah di sini tokoh raja ada ya? Siapa namanya?". } \\
\text { Fuadi : "Namanya Adnin Arnas". }\end{array}$ \\
\hline prckpn.7 & $\begin{array}{l}\text { Andy : Kalau gitu kita panggil tokoh aslinya langsung, Adni Arnas... } \\
\text { Andy : terima kasih sudah mau datang ya! Anda berhasil ditemukan. } \\
\text { (hahahahaha...... serentak ketawa bersama) } \\
\text { Karena kalau tidak kisah ini dianggap bohongan. Silakan duduk. } \\
\text { Fuadi : "Silakan!". }\end{array}$ \\
\hline prckpn.8 & $\begin{array}{l}\text { Andy : "Anda sudah baca blum bukunya?". } \\
\text { Admin : "Sudah". }\end{array}$ \\
\hline
\end{tabular}

\section{A. PEMBAHASAN}

\section{1) Analisis Topik Percakapan}

Sebuah percakapan selalu ada topik. Topik percakapan dalam percakapan Kick Andy pada episode ini dibagi menjadi dua topik yaitu topik umum dan topik kecil. Selain itu dalam percakapan Kick Andy pada episode ini juga ditemukan beberapa tipe topik pembicaraan: (1) topik yang berkelanjutan, (2) topik yang tidak berkelanjutan, (3) topik nyata, dan (4) topik imajiner.

\section{a. Topik Umum}

Topik umum yang terdapat dalam percakapan Kick Andy dengan Fuadi adalah "kisah tentang pengalaman pengarang dalam novel Negeri Lima Menara". Dikatakan demikian karena topik umum itu merupakan pokok pangkal pembicaraan yang berperan sebagai judul atau tema. Topik ini mengarahkan seluruh percakapan untuk mencapai tujuan percakapan. Hal ini dapat dilihat pada pengantar awal percakapan dan 
percakapan awal antara pembawa acara Kick Andy dengan Fuadi pengarang novel Negeri Lima Menara:

\section{Lihat data pngntr.I, pngntr.II, dan prckpn.1}

Berdasarkan pengantar percakapan tersebut Andy selaku pembawa acara Talk Show Kick Andy menyampaikan topik pembicaraan yang akan dibicarakan dalam percakapannya dengan Fuadi sekaligus memperkenalkan novel dan pengarang novel tersebut.

\section{b. Topik yang Berkelanjutan}

Topik berkelanjutan merupakan topik yang dikembangkan dalam percakapan dan topik yang dilanjutkan pada segmen percakapan berikutnya, baik itu dilanjutkan oleh pembawa acara maupun oleh orang yang diwawancarai.

Topik berkelanjutan terdapat dalam penggalan percakapan pertama, hingga percakapan ke-8. Lihat kode prckpn.1 sampai prckpn.8

Berdasarkan penggalan percakapan tersebut antara jawaban Fuadi dengan pertanyaan Andy berikutnya merupakan topik yang berkelanjutan. Hal ini disebabkan oleh jawaban Fuadi pada pertanyaan pertama yang memunculkan pertanyaan baru sebagai lanjutan percakapan. Fuadi menceritakan pengalamannya di pesantren yang dituangkan dalam tulisannya berupa sebuah novel.

Dari cerita pengalamannya itu muncul pertanyaan "mengapa judulnya Negeri Lima Menara?". Dalam cerita Fuadi, settingnya adalah pesantren tetapi judulnya Negeri Lima Menara, sehingga Andy kembali menanyakan judul cerita itu. Selanjutnya jawaban Fuadi kembali menjelaskan bahwa itu hanyalah simbol dari kisah para tokoh dalam novel tersebut.

Pada percakapan berikut, pertanyaan Andy tentang salah satu tokoh dalam novel itu bernama Raja, dan Fuadi mengiyakan dengan kata "betul”, dan Andy kembali menanyakan "siapa Raja itu?" di antara percakapan tersebut topik itu berkembang mulai dari cerita pengalaman, judul cerita, enam tokoh dalam cerita, Raja salah satu tokoh, cerita tentang tokoh Raja, cerita berbasis kisah nyata, tokoh Raja bernama Adnin Arnas.

Pengembangan topik ini diawali dengan jawaban Fuadi yang sekaligus menceritakan pengalaman bersama beberapa teman ketika di pesantren, dimana mereka 
mempunyai mimpi yang disimbolkan dengan Negeri Lima Menara. Dan topic itu berkembang sampai akhir percakapan ketika Andy menghadirkan Adnin Arnas yang dijadikan tokoh Raja dalam ceritanya.

\section{c. Topik Nyata}

Topik nyata merupakan topik pembicaraan yang menunujukan kefaktualisasi dalam sebuah percakapan, hal ini dapat dilihat pada penggalan percakapan. Lihat data prckpn.6-prckpn.8

Dengan dihadirkan Adnin Arnas sebagai tokoh asli dalam cerita Negeri Lima Menara, percakapan ini telah menunjukan bahwa cerita itu tidak bohong, dan sosok yang disebut-sebutkan sebelumnya ternyata ada.

\section{2) Analisis Struktur Percakapan}

Percakapan Andy dengan Fuadi dapat dibagi menjadi tiga bagian yakni: (1) awal percakapan; (2) inti Percakapan; (3) akhir percakapan.

\section{a. Awal Percakapan}

Ditemukan struktur pernyataaan pada awal percakapan yang dilakukan oleh pewawancara yang dalam pengantarnya memperkenalkan topik pembicaraan dan narasumber yang telah hadir dalam acara Talk show tersebut. Dengan demikian pewawancara berperan menjadi petunjuk atau penginformasi untuk satu percakapan yang akan dilaksanakan.

Struktur pernyataan yang dimaksud adalah sebagai ancangan akan berlanjutnya ujaran dari pelibat. Awal percakapan ketika dicermati, selain perkenalan yang disampaikan dengan pernyataan tersebut, pewawancara juga melanjutkan dengan memberi pertanyaan kepada narasumber. Berikut urutan awal percakapanan dalam percakapan Andy dengan Fuadi: lihat data pngntr.I, pngntr.II dan prckpn.1

Jika diperhatikan percakapan di atas, maka terdapat ancangan untuk berlanjut, hal ini ditandai dengan kalimat terakhir yang diucapkan Andy yakni "penulisnya sudah ada bersama kita Ahmad Fuadi" dan dilanjutkan dengan pertanyaan pertama pewawancara terhadap narasumber.

\section{b. Inti Percakapan}

Inti percakapan Andy dengan Fuadi ditandai dengan pertanyaan-jawaban yang dapat dilihat pada data prckpn.1 sampai prckpn.6 
Dalam penggalan percakapan ini pertanyaan dan jawaban mendominasi, diantaranya pada pertanyaan pertama oleh ujaran pertama, kedua dan seterusnya sampai akhir percakapan, demikian juga dengan ujaran kedua yakni penjawab. Ketika dicermati ada pula tindak lanjut yakni Fuadi menjawab pertanyaan Andy dengan sedikit menceritakan pengalamannya. Dengan demikian dapat dikatakan bahwa penjawab merespon pertanyaan penanya dengan tindak lanjut yakni menjawab sesuai dengan pertanyaan yang diajukan padanya, sehingga dengan sendirinya penjawab berperan sebagai perespon dan pelanjut dengan baik dalam percakapan tersebut.

Selanjutnya pada pertanyaan kedua, penanya menjadi pelanjut atas responnya terhadap jawaban (cerita) penjawab dengan mengemukakan pertanyan baru agar mendapat informasi lanjutan, dan seterusnya dalam pertanyaan dan jawaban yang lain.

Berdasarkan analisis tersebut inti percakapan dapat diklasifikasikan menjadi ujaran pertama (pewawancara) termasuk dalam permintaan dan pertanyaan; sedangkan ujaran kedua (narasumber) termasuk dalam pengabulan dan jawaban yang diharapkan. Dengan demikian percakapan yang dilakukan antara ujaran pertama dan ujaran kedua sudah terjadi pertukaran informasi.

\section{c. Akhir Percakapan}

Pada akhir percakapan Andy dengan Fuadi ditandai dengan: pertanyaanjawaban, permintaan-pengabulan, ucapan terimakasih. Dapat dilihat pada data

\section{prckpn.6-prckpn.8}

Berdasarkan penggalan percakapan di atas ujaran pertama oleh Andy memberikan pertanyaan dalam kalimat "nah di sini ada tokoh Raja ya? Siapa namanya?" dan Fuadi selaku ujaran kedua hanya menjawab "namanya Adnin Arnas" seharusnya mengiyakan atau tidak mengiyakan sebelum mengatakan nama Adnin Arnas. Dari hasil analisis ini disimpulkan bahwa Penjawab atau ujaran kedua langsung menjawab dan jawabannya sudah mewakili pertanyaan pertama tadi, maksudnya jika disebutkan nama berarti memang ada tokoh yang berperan sebagai Raja dalam cerita tersebut.

Selanjutnya permintaan-pengabulan dapat dilihat pada ujaran pertama (pewawancara) yang memanggil Adnin Arnas untuk hadir dalam acara percakapan Kick Andy yang sedang berlangsung. Kehadiran Adnin disambut dengan tepuk tangan merupakan suatu pengabulan permintaan, dan ucapan terima kasih dilanjutkan dengan 
tindakan mempersilahkan Adnin untuk duduk disertai lontaran sebuah pertanyaan merupakan lanjutan percakapan terhadap orang kedua yang diwawancarai Andy. Sebenarnya percakapan dalam Kick Andy belum selesai, karena kehadiran tamu berikut merupakan lanjutan percakapan, tetapi dapat dikatakan akhir dalam bentuk jedah yang dihadirkan.

Perlu diperhatikan bahwa perckapan yang dianalisis hanyalah percakapan pada termin pertama tentang pengalaman penulis dan teman-temannya dalam novel Negeri Lima Menara.

\section{3) Analisis Alih Tutur}

Percakapan Andy dengan Fuadi dalam acara Talk Show merupakan percakapan yang melibatkan tiga partisipan, yaitu Kick Andy sebagi Host, Ahmad Fuadi dan adnin Arnas sebagai bintang tamu. Kick Andy sebagai partisipan tetap, sedangkan Fuadi dan Arnas sebagai partisipan yang bergantian. Berdasarkan analisis terhadap alih tutur ditemukan dua tipe alih tutur dalam percakapan pembawa acara dengan bintang tamu.

\section{a. Alih Tutur dengan Giliran Diatur.}

Adanya pertanyaan-jawaban. Alih tutur ini terjadi ketika pembawa acara (host) memberi kesempatan kepada bintang tamu untuk menjawab pertanyaan yang diajukan oleh host. Berikut sampel data yang terkait dengan alih tutur giliran diatur. Dapat dilihat pada data prckpn.1

Pada kalimat prckpn.1 Fuadi memperoleh giliran bicara setelah dipersilakan oleh Andy selaku pembawa acara. Ujaran "jawaban Fuadi pada data prckpn.1" merupakan penanda bahwa Fuadi mendapatkan giliran bicara. Adapun jawaban Fuadi "Bahwa saya itu awalnya masuk pesantren...orang lain terinspirasi" sebagai pengembangan dari jawaban pokok.

Data lain, juga peneliti temukan pada ungkapan Arnas, Ia memberikan jawaban atas apa yang ditanyakan Andy. Andy memberikan jawaban kepada Arnas untuk menjawab yang diajukan oleh Andy.

Tampak jelas dalam percakapan data prckpn.8 Arnas berbicara setelah dipersilakan oleh Andy, dan bentuk mempersilakan tersampaikan secara tersirat. 
Kalimat “Anda sudah baca belum bukunya?"dengan respon yang cepat sekali Arnas lansung menjawab pertanyaan Andy.

\section{b. Alih Tutur dengan Giliran Otomatis}

Alih tutur dengan giliran otomatis mengikuti struktur pasangan ujar terdekat. Ujaran seorang penutur sebagai pemicu secara otomatis direspon oleh penanggap tutur. Dalam percakapan acara Kick Andy, alih tutur dengan giliran otomais terjadi ketika ujaran dari salah satu partisian sebagai pemicu secara otomatis di respon oleh partisipan yang lain.

Alih tutur dengan giliran otomatis ini mengikuti struktur pasangan ujar terdekat. Alih tutur dengan giliran otomatis, peneliti temukan pada sapaan yang disampaikan Andy "Silakan duduk " kepada Arnas, kemudian Fuadi menyahutnya secara spontan “Silakan!". Di sini sahutan dari Fuadi nampak jelas, bahwa Ia ikut menyahut tanpa sengaja atau spontan.

\section{4) Analisis Kepaduan Wacana Percakapan}

Kohesi wacana merupakan kepaduan wacana yang dibangun dengan menggunakan penanda atau alat-alat tertentu yang dapat diamati. Kohesi merupakan kepaduan wacana yang dibangun dengan tidak menggunakan penanda katon. Sedangkan koherensi merupakan keterpautan makna antara percakapan yang satu dengan yang lainnya.

Andy sebagai penanya dan Ahmad Fuadi sebagai orang yang ditanya. Berdasarkan hasil analisis terhadap kepaduan wacana percakapan ditemukan bahwa terjalinnya kepaduan dalam percakapan dari awal hingga akhir.

- Ketika Andy bertanya novel negeri lima menara bercarita tentang apa, di situ Fuadi menjawab tentang sebuah kenangan.

- Ketika Fuadi ditanya mengapa diberi judul negeri lima menara, Fuadi menjawab karena lima menara menggambarkan impian dari enam temannya. Lima menara tersebut sebagai gambaran dari bernua Amerika, benua eropa dll. Jawaban yang disampaikan Fuadi bersifat implisit, karena penyampaiannya tidak secara langsung.

- Saat ditanya Siapa tokoh raja yang ada dalam cerita?, Fuadi dengan tpat menjawab : namanya Adnin Arnas. 


\section{SIMPULAN}

Berdasakan hasil pembahasan di atas, dapat diketahui bahwa analisis percakapan yang terdapat dalam video acara Talk Show Kick Andy memuat empat pokok bahasan, terdiri atas: topik percakapan, struktur percakapan, alih tutur percakapan, dan kepaduan wacana percakapan.

Dalam topik percakapan memuat empat topik, yakni topik umum, topik yang berkelanjutan, topik yang tidak berkelanjutan dan topik nyata. Topik umum ditemukan pada pengantar awal percakapan, sedangkan topik yang berkelanjutan ditemukan pada keseluruhan percakapan. Untuk topik yang tidak berkelanjutan ditemukan pada percakapan yang singkat, karena topik percakapannya tidak dikembangkan. Sedangkan topik nyata ditemukan pada akhir percakapan hadirnya Arnas yang berperan sebagai raja dalam cerita.

Struktur percakapan yang dibahas terdiri atas awal percakapan yang memuat tentang memperkenalkan topik pembicaraan yang akan dibahas bersama narasumber. Sedangkan inti percakapan memuat pertanyaan-jawaban, dan permintaan-pengabulan. Selanjutnya akhir percakapan disoroti pada akhirnya percakapan antara Andy dan Fuadi tokoh lain dihadirkan.

Adapun alih tutur percakapan berisi dua tipe alih tutur percakapan. Pertama alih tutur dengan giliran diatur, kedua Alih tutur dengan giliran otomatis. Alih tutur dengan giliran otomatis mengikuti struktur pasangan ujar terdekat. Pada alih tutur dengan giliran diatur adanya pada pertanyaan-jawaban, pertanyaan yang diajukan Andy dijawab oleh Fuadi secara bergiliran. Adapunalih tutur giliran otomatis muncul pada tanggapan Fuadi yang secara spontan ikut mempersilakan Arnas untuk duduk.

Analisis percakapan yang terkhir yaitu kepaduan wacana percakapan. Kepaduan ditunjukkan pada kohesi dan koherensi yang ada dalam isi percakapan dari awal hingga akhir percakapan.

\section{SARAN}

Kajian linguistik, khususnya mengenai analisis percakapan sangatlah luas. penelitian lebih lanjut dapat diarahkan pada penelitian yang lebih komprehensif. misalnya khusus meneliti struktur percakapan. Di situ nanti akan dapat memperoleh pengajian yang lebih intens dalam mengupas data berdasarkan teori khusus struktur 
percakapan. Ini juga dapat dikembangkan penelitian lainnya yang masih ada hubungan dengan analisis percakapan.

\section{REFERENSI}

Brown, Gillian dan George Yule. 1996. Analisis Wacana. Penerjemah I. Soetikno. Jakarta: P.T. Gramedia.

Coulthard, Malcolm. 1985. An Introduction to Discourse Analysis. New York: Longman.

Djajasudarma, T. Fatimah. 1994. Wacana Pemahaman dan Hubungan antar Unsur. Bandung: Eresco.

Halliday, MAK, dan Hasan. 1976. Cohesion in English. London: Longman.

Howe, Christine. 1981. Acquiring Languange in Converstional Context. London: Academic Press Inc.

Kridalaksana, harimurti. 2011. Kamus Linguistik Edisi Keempat. Jakarta: Gramedia Pustaka Utama.

Levinson, Stephen C. 1983. Pragmatics. Cambrige: Cambridge University Press.

Parera. J. D. 1991. Teori Semantik. Jakarta: Airlangga.

Rani, Abdul. 1992. Analisis Percakapan Anak-anak Antarteman Sebaya. Tesis Tidak dipublikasikan. Malang: PBS IKIP Malang.

Samsuri. 1988. Analisis Wacana. Malang: IKIP Malang.

Schiffrin, Deborah. 1994. Approach to Discourse. Cambridge: Black Well Publishers.

Sudaryanto. 1993. Metode dan Aneka Teknik Analisis Bahasa (Pengantar Penelitian Wahana Kebudayaan Secara Linguistis).Yogyakarta:DutaWacana University Press.

Syamsudin. 1992. Studi Wacana Teori-Analisis-Pengajaran. Bandung: Mimbar Pendidikan Bahasa dan Seni FPBS IKIP Bandung.

Widdowson, H. G. 1978. Teahing Languange As Communication. Oxford: University Press. 